\title{
Level of Heavy Metals in Soil Samples from Farmlands along Highways in Parts of Owerri, Nigeria
}

\author{
Okereke J. N., Nduka, J. N., Ukaoma, A.A., Ogidi I. O.
}

\begin{abstract}
The research was designed to ascertain the concentrations of heavy metals $(\mathrm{Cu}, \mathrm{Pb}, \mathrm{Zn}, \mathrm{Ni}, \mathrm{Cd})$ in soil samples from farmlands along highways in parts of Owerri. Soil samples were collected from cassava farms along three major roads with high traffic density and a rural road that served as control location, for possible heavy metals contamination due to vehicular emission. Standard laboratory procedures were adopted to determine the concentration of heavy metals using Atomic Absorption Spectrophotometer (AAS). Contamination factor (CF) and Pollution Load Index were mathematically calculated. The results revealed that the mean concentrations of metals in soil samples in $\mathrm{mg} / \mathrm{kg}$ ranged from $3.00-6.31$ for $\mathrm{Cu}$; $\mathrm{Pb}, 0.09$ - 4.00; Zn, 3.97 - 8.59; Ni, 0.001 - 0.96; and Cd, 0.31 0.79. These metals showed decrease in concentrations with increase in distance away from the highway. The values of contamination factor (CF) were low except for $\mathrm{Cd}$ and Pollution Load Index (PLI) for all soil studied showed no sign of pollution. There was no correlation between traffic density and concentration of heavy metal in soil except for $\mathrm{Cd}(\mathrm{Rs}=\mathbf{0 . 8 0 0})$. The overall results showed evidence of some heavy metal pollution on the soils with possible cumulative effect over time.

Index Terms - Level, Heavy Metals, Soil, Farmlands,
\end{abstract} Highways, Owerri.

\section{INTRODUCTION}

Roads serve as major links among communities through which foods and other important commodities are transported. It is an essential amenity that plays a major role in enhancing social and economic activities. However, road construction has also resulted in heavy environmental pollution especially on soils (Bai et al., 2009). Environmental pollutants are widely distributed in air, water, soils and sediments. Among environmental pollutants, metals are of particular concern, due to their potential toxic effects and ability to bio-accumulate in ecosystems (Censi et al., 2006). Reports have shown that roadside soils may be contaminated from various anthropogenic activities such as industrial and energy production, vehicle exhaust, waste disposal as well as coal and fuel combustion (Li et al., 2001). These activities send trace metals into the air and the metals subsequently deposited into nearby soils, which are absorbed by plants on

Okereke J. N., Department of Biotechnology, School of Biological Sciences, Federal University of Technology, Owerri, Nigeria

Nduka, J. N., Department of Biotechnology, School of Biological Sciences, Federal University of Technology, Owerri, Nigeria

Ukaoma, A.A., Department of Biology, School of Biological Sciences, Federal University of Technology, Owerri, Nigeria

Ogidi I. O., Department of Science Laboratory Technology, Federal Polytechnic, Ekowe, Bayelsa, Nigeria such soils. Public motor roads affect natural environment to a large extent because automobiles act as line sources of heavy metal pollutants (Poszyler-Adamska \& Czemiak, 2007). Samples of soil from lands near motorways in some urban cities in Nigeria such as Jos, Osogbo, Ibadan and other cities, have been studied (Abechi, et al., 2010; Fakayode \& Olu-Owolabi, 2003; Onianwa, 2001; Ihenyen, 1998). Again, roadside soils in UK (Thornton, 1982), Holland (Edelman \& Bruin, 1986), India (Kuhad et al., 1989), and Botswana (Mmolawa et al., 2011), have also been studied. Roadside soil pollution in these studies was attributed to traffic. Thus, emissions from heavy traffic are a global phenomenon. Copper, Zinc, Cadmium, and Lead are the typical metal pollutants due to traffic activities.

With the rapid increase in number of motor vehicles on highways recently, and consequent boost in commercial and industrial activities; ranging from vehicle repairs, vulcanizing and welding to auto-electricians, battery chargers and dealers in other facilitators of motor transportation (Taofeek \& Tolulope, 2012), considerable amounts of some heavy metals are likely to be emitted regularly as long as the nearby sources remain active.

Studies on heavy metals pollution of soil have been reported widely in literature over the years. Zauro et al. (2013) investigated extent of some heavy metal contamination in soil of farmlands around Sokoto metropolis. Concentration of $\mathrm{Cd}, \mathrm{Cr}, \mathrm{Cu}, \mathrm{Pb}$ and $\mathrm{Zn}$ in all the soils samples ranged from $0.20-39.975 \mathrm{ug} / \mathrm{g}$ dry weight. Olatunji et al. (2013) carried out research on heavy metal concentrations in selected arable agricultural soils in South-Western Nigeria and reported that the application of micronutrient supplements such as fertilizer, animal manure and sewage sludge in bid to enhance soil productivity and crop yield, poses the risk of heavy metals elevation and nutrients depletion in arable lands. Okereke et al. (2014) evaluated level of heavy metals in agricultural lands in Idemili, Anambra and documented high concentrations of heavy metals of public health importance such as Lead $(\mathrm{Pb})$. In another study of heavy metals in soil around Wukari, Achadu et al. (2015) carried out a research work on "assessment of heavy metals $(\mathrm{Pb}, \mathrm{Cd}, \mathrm{Zn}$ and $\mathrm{Cu})$ concentrations in soils along a major highway in Wukari, North-Eastern Nigeria". The extent of the heavy metals contamination was assessed, as analytical data were subjected to pollution calculation methods. The contamination factors (CF) revealed extreme contamination of the sites and an increased trend in the heavy metal concentrations was 
observed in sites with more human activities. Again, the pollution load index (PLI) showed that the sites were severely polluted as the PLI of the metals from each sample site exceeded the PLI of the background (control) sample (0.7). They concluded that the study sites pollution is mostly due to automobile emissions.

Heavy metals in roadside soils of major streets in Jos metropolis have been evaluated and correlated to traffic volume with decreasing order of the average total levels of the studied metals: $\mathrm{Fe}>\mathrm{Zn}>\mathrm{Mn}>\mathrm{Pb}>\mathrm{Cd}>\mathrm{Cu}$ (Abechi et al., 2010).

Christopher \& Therese (2010) studied heavy metal contamination of surface soil in relationship to land use patterns in Benue State to assess soil environmental quality. Results revealed that metals levels were generally high in mineralized and urban soils and lower in agricultural soils whilst forest soils were polluted by anthropogenic sources. Mineralized soils developed from weathered sulphides were rich in lead $(\mathrm{Pb})$, zinc $(\mathrm{Zn})$, and cadmium $(\mathrm{Cd})$. Urban soils accumulated $\mathrm{Cu}, \mathrm{Zn}$, and $\mathrm{Cd}$ most probably from refuse dumps, gasoline combustion and farming. Agricultural soils were enriched in arsenic (As) and to a lesser degree, $\mathrm{Pb}$ and $\mathrm{Cd}$, originating most probably from the application of pesticides, manure and fertilizers. A pollution index (PI) based on plant-tolerant contamination levels, indicates that multi-element contamination in soils is low and implies that the sampled soils could be cultivated for crop production

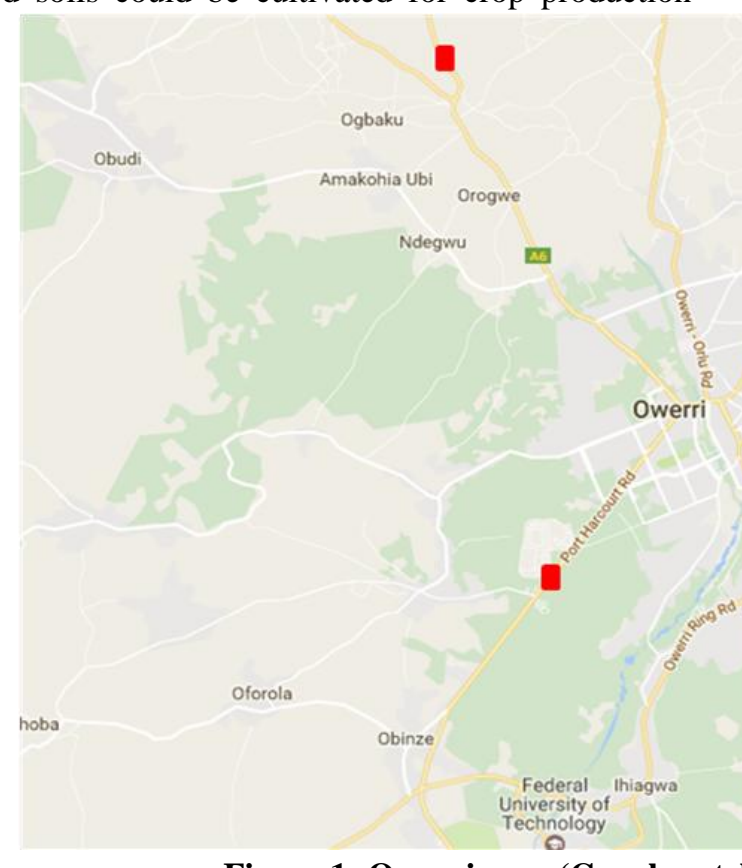

Figure 1: Owerri map (Google satellite map, 2016) Sample Collection

A total of 12 samples of soil were randomly collected from farm lands near highways in parts of Owerri, Nigeria. Three locations situated along busy roads were selected: Onitsha-Owerri road, PortHarcourt-Owerri road, and Aba-Owerri road. Another location, characterized by low traffic densities, Oforola, a rural settlement was selected as control. This location is sparsely populated and basically residential with no industrial activities. Soils were sampled at $0-10 \mathrm{~cm}$ depth at distance intervals of 10, 15, and 20meters from the roadway using a surface-sterilized auger and put into a polythene bag. Three soil samples were taken from three points from each distance and mixed together to form especially away from point sources of pollution. High traffic density has been linked with high levels of heavy metals $(\mathrm{Pb}$, $\mathrm{Cd}, \mathrm{Cr}$, and $\mathrm{Zn}$ ) in soil from roadsides in Ogbomoso, Nigeria (Adelasoye \& Ojo, 2014). The heavy metal distribution inwards from the edge of the road did not show consistency up to $30 \mathrm{~m}$. Increase in metallic levels at a distance beyond 35 $\mathrm{m}$ off the road edge is reported to be attributed to geological and/or biological decomposition of leaf litters (Luilo \& Othman, 2006)

\section{MATERIALS AND METHODS}

\section{Study Area}

The sampling locations were chosen to span a wide range of traffic density and to give a good geographical coverage in Owerri, Imo State. Owerri consists of three Local Government Areas including Owerri Municipal, Owerri North and Owerri West; it has an estimated population of about 401,873 as of 2006 and is approximately 100 square kilometres in area. Geographic coordinates of Owerri, lies within Latitude: $5^{\circ} 29.0178^{\prime}$ North, Longitude: $7^{\circ} 1.995^{\prime}$ East with elevation above sea level: $73 \mathrm{~m}=239 \mathrm{ft}$. Owerri has a tropical wet climate with average temperature is $26.4{ }^{\circ} \mathrm{C}$. Some major roads that go through the city are: PortHarcourt road, Aba road, Onitsha road, and Okigwe road with other roads within the city. Three sites selected for study is shown in Figure 1.

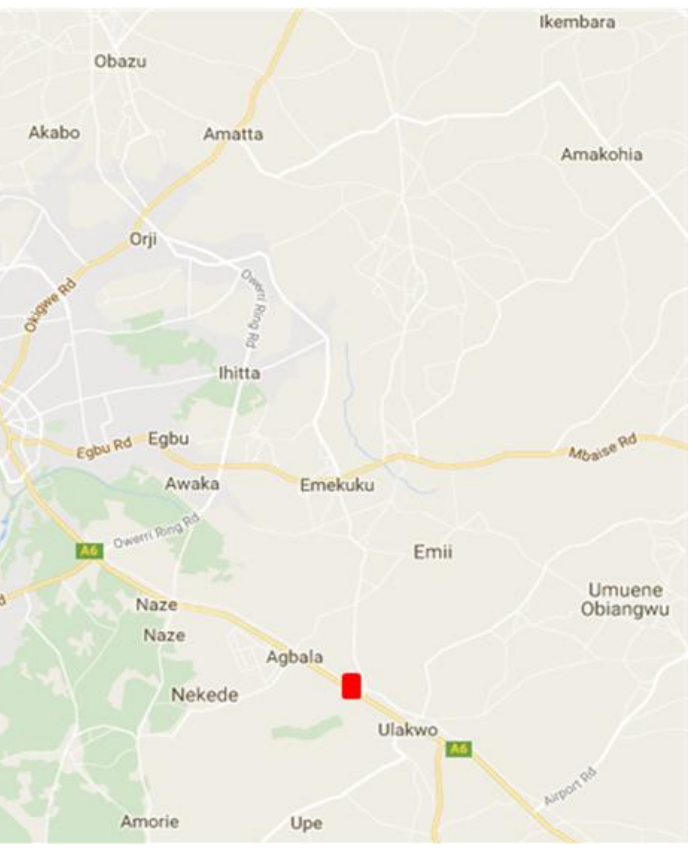

composite samples and transported to the laboratory for analyses.

\section{Soil Sample Preparation and Digestion}

All clods and crumbs were removed from the soil samples, then, mixed uniformly and air-dried. Soils were sieved through a $2 \mathrm{~mm}$ sieve to remove coarse particles before sub-sampling for chemical analysis. Measured $0.5 \mathrm{~g}$ of air-dried ground soil was transferred to $25 \mathrm{ml}$ conical flask; $5 \mathrm{ml}$ of concentrated $\mathrm{H}_{2} \mathrm{SO}_{4}$ was added followed by $25 \mathrm{ml}$ of concentrated nitric acid $\left(\mathrm{HNO}_{3}\right)$ and $5 \mathrm{ml}$ of concentrated hydrochloric acid $(\mathrm{HCl})$. The contents of the tube were heated at $200^{\circ} \mathrm{C}$ for $1 \mathrm{hr}$ in a fuming hood and then cooled to room 
temperature. After cooling, $20 \mathrm{ml}$ of distilled water was added and the mixture was filtered to complete the digestion. Finally, the mixture was transferred to a $50 \mathrm{ml}$ volumetric flask, filled to the mark and left to settle for at least 15 hours. The filtrate was analyzed for total $\mathrm{Cu}, \mathrm{Fe}, \mathrm{Mn}, \mathrm{Pb}, \mathrm{Zn}, \mathrm{Ni}$, and Cd using Atomic Absorption Spectrometer (AA500F).

\section{Heavy Metal Analysis}

The determination of the heavy metals $(\mathrm{Cu}, \mathrm{Pb}, \mathrm{Zn}, \mathrm{Ni}$, and Cd) content of the cassava and soil samples respectively was carried out according to the standard procedures of the Atomic Absorption Spectrophotometer (AAS). In each case, the hollow cathode lamp of the element under investigation, the analyte elements were fixed in the burret assembly of the atomic absorption spectrophotometer. The instrument was switched on. The fuel and oxidant used were acetylene and compressed air respectively. The burner was lit and a flame established from the acetylene compressed air as fuel/oxidant. The standard solution of each element under investigation was aspirated into the nebuliser-burner assembly and the corresponding absorbance reading obtained from the digital read out of the Atomic Absorption Spectrophotometer at the wavelength of the element under investigation. This was followed by the aspiration of the sample solution and the absorbance reading obtained from the digital read out. The concentration of the element in the sample was obtained by extrapolation from the standard curve. This was repeated for the entire element under investigation using their hollow cathode lamp and at their different wavelengths.

\section{Pollution Load Index of Soil along Highways}

The degree of soil pollution for each metal was measured using the pollution load index (PLI) technique which depends on soil metal Contamination factor $(\mathrm{CF})$

The level of contamination of soil by metal is expressed in terms of a contamination factor (CF) calculated as:

$\mathrm{CF}=\frac{\mathrm{G}}{\mathrm{a}} \ldots . . . .$. Equation 1

Where; Cs is the concentration of heavy metal in soil and $\mathrm{Cb}$ is background value for heavy metal using the values from DPR-EGASPIN (2012) due to metal background values have not been reported yet for the study area. The classification of contamination factor is: $\mathrm{CF}<1$, refers to low contamination; $1 \leq \mathrm{CF}<3$, means moderate contamination; $3 \leq \mathrm{CF} \leq 6$ indicates considerable contamination and $\mathrm{CF}>6$ indicates very high contamination.

Each site was evaluated on the extent of metal pollution by employing the method based on the pollution load index
(PLI) as follows:

$\mathrm{PLI}=\left(\mathrm{CF}_{1} \times \mathrm{CF}_{2} \times \mathrm{CF}_{3} \times \ldots . . \mathrm{CF}_{\mathrm{n}}\right)^{1 / \mathrm{n}} \ldots \ldots .$. Equation 2

Where $\mathrm{n}$ is the number of metals studied (five in this study) and $\mathrm{CF}$ is the contamination factor calculated as described in Equation 1. The PLI provides simple but comparative means for assessing a site quality, where a value of PLI $<1$ denotes perfection; PLI $=1$, presents that only baseline levels of pollutants are present, and PLI > 1 would indicate deterioration of site quality. The following modified equation was used to assess the PLI level in soils.

$\mathrm{PLI}=\mathrm{C}_{\text {Soil }}($ Sample $) / \mathrm{C}_{\text {Refernce }}$ (Reference)

Equation 3

Where; $\mathrm{C}_{\text {soil }}$ (Samples) and $\mathrm{C}_{\text {reference }}$ (Reference) represent the heavy metal concentrations in the soil proximal to roadsides and reference soils respectively (Liu et al., 2005).

\section{Statistical Analysis}

Data generated were analyzed using the Statistical Package for Social Sciences 10. The data were expressed in terms of descriptive statistics while the figures were presented with mean values of triplicates. The statistical significance was computed using pair samples $\mathrm{T}$-test at $\mathrm{P}<0.05$

\section{RESULTS}

Mean concentrations of Heavy metals in farmlands along Highways

The mean concentrations of heavy metal in farmlands along highways in parts of Owerri are shown in Table 3.1 with Owerri-Onitsha road recording levels of $\mathrm{Cu}, \mathrm{Pb}, \mathrm{Zn}, \mathrm{Ni}$, $\mathrm{Cd}$, as $6.16 \mathrm{mg} / \mathrm{kg}, \quad 2.59 \mathrm{mg} / \mathrm{kg}, \quad 6.86 \mathrm{mg} / \mathrm{kg}, \quad 0.76 \mathrm{mg} / \mathrm{kg}$, $0.55 \mathrm{mg} / \mathrm{kg}$ respectively. Owerri-PortHarcourt road recorded highest value of $6.08 \mathrm{mg} / \mathrm{kg}$ and least value of $0.5467 \mathrm{mg} / \mathrm{kg}$ of $\mathrm{Ni}$ while Owerri-Aba road also recorded highest value $(6.23 \mathrm{mg} / \mathrm{kg})$ of $\mathrm{Cu}$ and least value $(0.58 \mathrm{mg} / \mathrm{kg})$ of $\mathrm{Ni}$.

The overall metal concentrations $(\mathrm{Cu}, \mathrm{Pb}, \mathrm{Zn}, \mathrm{Ni}$, and $\mathrm{Cd}$,) in soils of the sampling sites at different distances are presented in Figures $2 \mathrm{a}-2 \mathrm{e}$. The level of copper in soil samples along Owerri-Aba road ranged from $6.18 \mathrm{mg} / \mathrm{kg}$ $6.23 \mathrm{mg} / \mathrm{kg}$ while Owerri-Onitsha road recorded highest copper content at $15 \mathrm{~m}$ distance with $6.33 \mathrm{mg} / \mathrm{kg}$. The level of $\mathrm{Pb}$ at $10 \mathrm{~m}, 15 \mathrm{~m}, 20 \mathrm{~m}$ away, recorded lower values along Owerri-Aba road compared to higher values recorded along Owerri-Portharcourt road. Zn level along Owerri-Onitsha road fluctuated between were $9.82 \mathrm{mg} / \mathrm{kg}$ and $5.90 \mathrm{mg} / \mathrm{kg}$ as the control location recorded low values of $\mathrm{Cd}$ and $\mathrm{Ni}$ at $10 \mathrm{~m}$, $15 \mathrm{~m}, 20 \mathrm{~m}$ respectively.

Table 1: Mean concentrations of heavy metals in soil samples from farmlands along highways in Owerri

$\begin{array}{llll}\begin{array}{c}\text { Heavy } \\ \text { metal }\end{array} & \text { OWR-OSH } & \text { Concentrations }(\mathrm{mg} / \mathrm{kg}) & \\ \text { OWR-PHC } & \text { OWR-ABA } & \text { Control }\end{array}$

\begin{tabular}{lllll}
\hline & & & & \\
$\mathrm{Cu}$ & $6.16 \pm 0.0436$ & $6.08 \pm 0.01$ & $6.237 \pm 0.0751$ & $3.0533 \pm 0.0503$ \\
$\mathrm{~Pb}$ & $2.5867 \pm 1.2309$ & $1.416676 \pm 0.878$ & $2.75 \pm 0.661$ & $0.1033 \pm 0.0153$ \\
$\mathrm{Zn}$ & $6.86 \pm 1.4982$ & $5.983 \pm 0.0153$ & $5.973 \pm 0.0577$ & $4.0667 \pm 0.1343$ \\
$\mathrm{Ni}$ & $0.7567 \pm 0.176$ & $0.5467 \pm 0.0929$ & $0.5833 \pm 0.0586$ & $0.0001 \pm 0$ \\
$\mathrm{Cd}$ & $0.553 \pm 0.208$ & $0.5777 \pm 0.1319$ & $0.8367 \pm 0.117$ & $0.323 \pm 0.0152$ \\
\hline
\end{tabular}

Legends: OWR-OSH: Owerri-Onitsha road; OWR-PHC: Owerri-PortHarcourt road; OWR-ABA: Owerri-Aba road. 


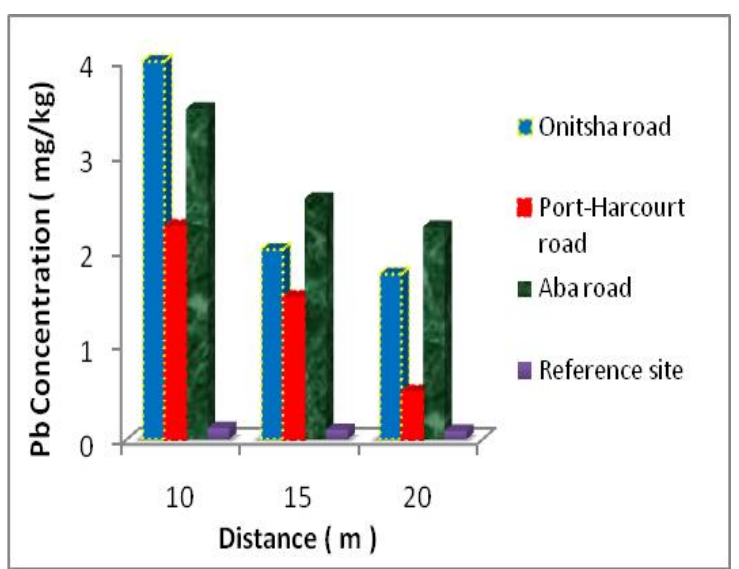

Figure 2a: Total $\mathrm{Cu}$ level in soil samples

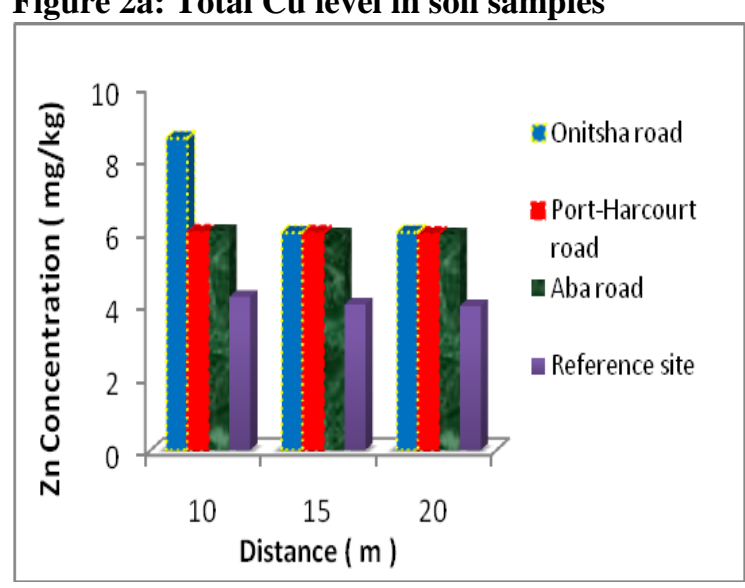

Figure 2b: Total $\mathrm{Pb}$ level in soil samples

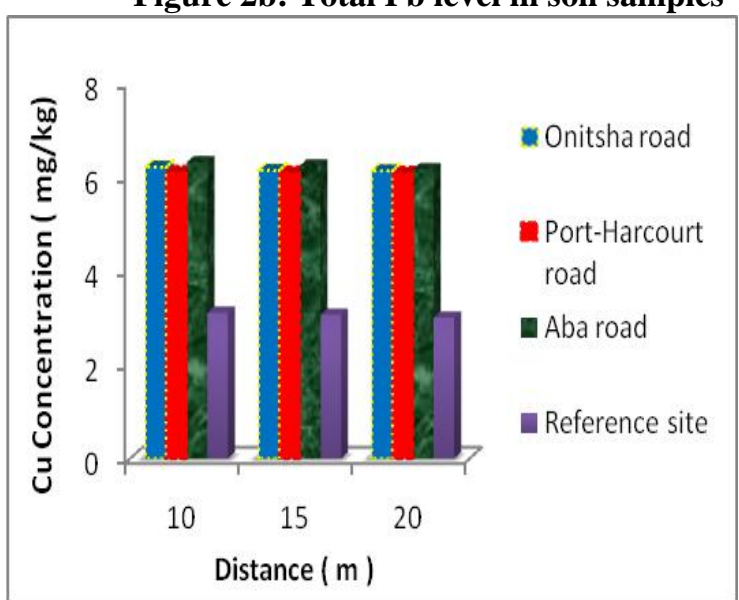

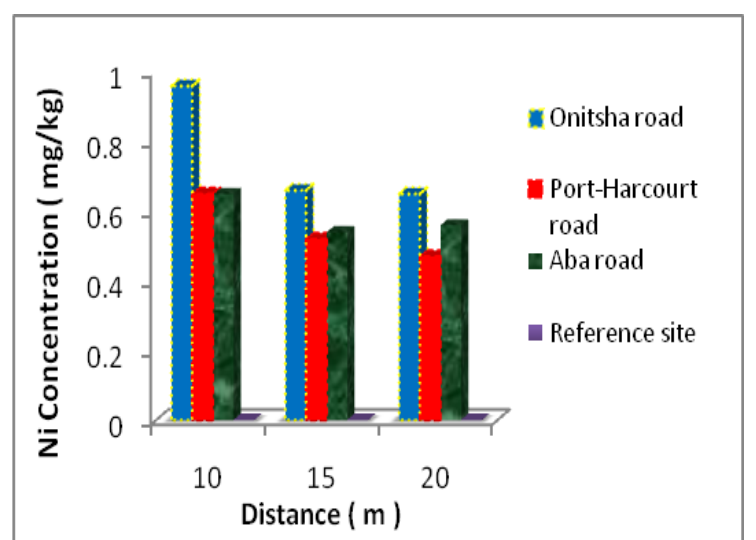

Figure 2d: Total Ni level in soil samples

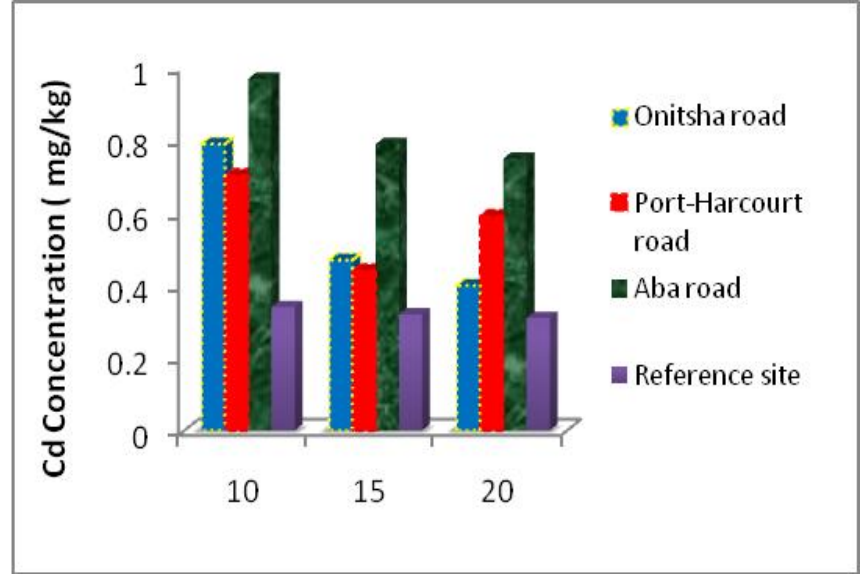

Figure 2e: Total Cd level in roadside soils

Contamination factor and Pollution load Index

Using the contamination factor categories previously described, all the sites had low contamination of the heavy metals except along Owerri-Aba road, which had moderate contamination of Cadmium (1.05) (Table 2).

Figure 3 shows the result of the PLI for the three sites. Based on the result, the three sites could be said to be in a pristine condition because they showed no sign of pollution.

Figure 2c: Total Zn level in soil samples

\begin{tabular}{cccc}
\multicolumn{4}{c}{ Table 2: Contamination factor of heavy metals } \\
\hline METAL & $\begin{array}{c}\text { Contamination Factor } \\
\text { OWR-PHC }\end{array}$ & $\begin{array}{c}(\mathbf{m g} / \mathbf{k g}) \\
\text { OWR-OSH }\end{array}$ & OWR-ABA \\
\hline $\mathrm{Cu}$ & 0.171 & 0.169 & 0.173 \\
$\mathrm{~Pb}$ & 0.030 & 0.017 & 0.032 \\
$\mathrm{Zn}$ & 0.049 & 0.043 & 0.043 \\
$\mathrm{Ni}$ & 0.022 & 0.014 & 0.017 \\
$\mathrm{Cd}$ & 0.686 & 0.725 & 1.05 \\
\hline
\end{tabular}

Legends: ONITSHA- Onitsha-Owerri road; PH- Portharcourt- Owerri road; ABA- aba-Owerri road. 


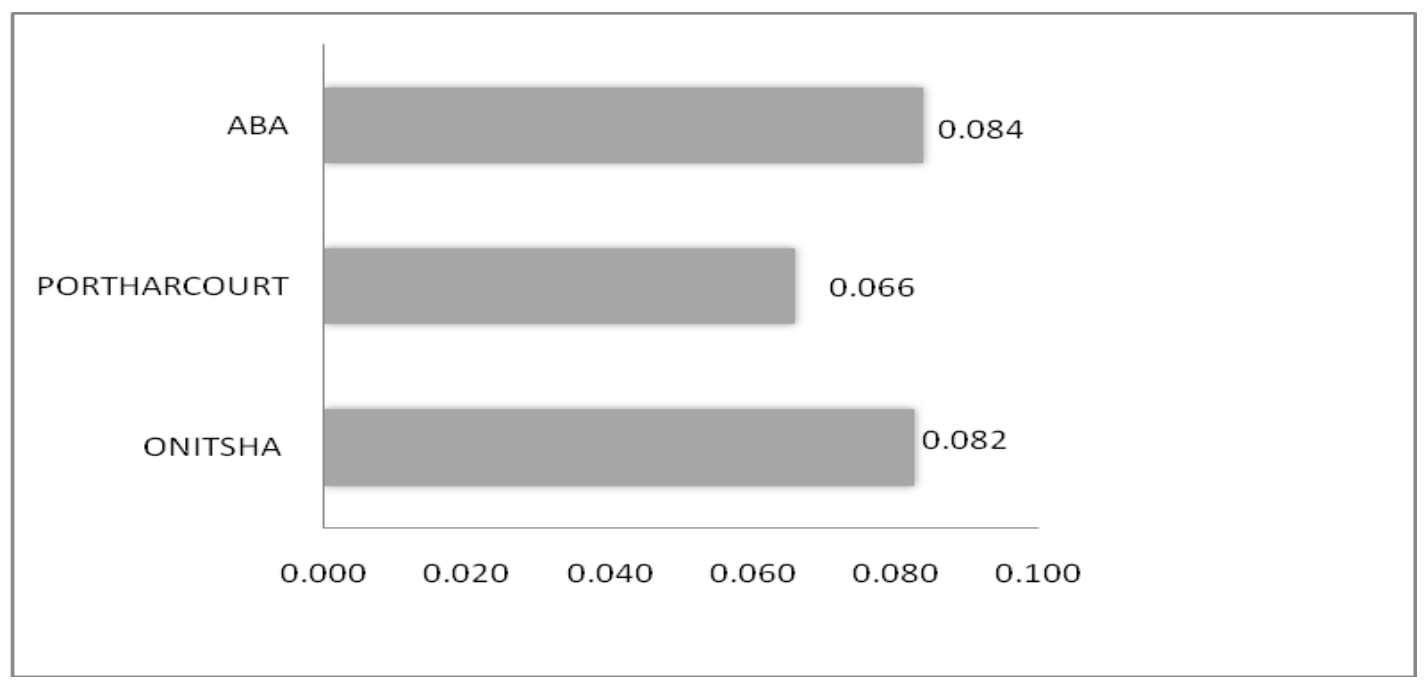

Figure 3: Pollution Load Index of sampled areas

Statistical correlation of heavy metals in soil at different distance

In comparing the mean difference in heavy metal concentration between distance and Cassava soil, only $\mathrm{Cu}$ and $\mathrm{Ni}$ showed significant increase in concentration at $\alpha=0.05$ as one moves from the $20 \mathrm{~m}$ region to the $10 \mathrm{~m}$ region (Table 3 ). Though there was no significant difference in the mean difference on concentration of the other heavy metals $(\mathrm{Pb}, \mathrm{Zn}$ and $\mathrm{Cd})$, the values showed an increasing trend as one moves from the $20 \mathrm{~m}$ region to the $10 \mathrm{~m}$ region.

Table 3: Mean difference in concentrations between distance and farmland soil.

\begin{tabular}{llccccc}
\hline Metal & $\mathbf{1 0}-\mathbf{1 5 m}$ & $\begin{array}{c}\text { Sig. } \\
\text { diff }\end{array}$ & $\mathbf{1 5}-\mathbf{2 0 m}$ & $\begin{array}{c}\text { Sistance } \\
\text { diff }\end{array}$ & $\mathbf{1 0 - 2 0 m}$ & Sig. diff \\
\hline $\mathrm{Cu}$ & $0.0675 \pm 0.02611$ & 0.042 & $0.00 \pm 0.02611$ & 1.000 & $0.0675 \pm 0.02611$ & 0.042 \\
$\mathrm{~Pb}$ & $0.3675 \pm 0.53103$ & 0.520 & $0.9400 \pm 0.53103$ & 0.137 & $0.5725 \pm 0.53103$ & 0.330 \\
$\mathrm{Zn}$ & $0.6975 \pm 0.52070$ & 0.229 & $0.0100 \pm 0.52070$ & 0.985 & $0.6875 \pm 0.52070$ & 0.235 \\
$\mathrm{Ni}$ & $0.13500 \pm 0.05302$ & 0.044 & $0.0100 \pm 0.05302$ & 0.857 & $0.14500 \pm 0.05302$ & 0.034 \\
$\mathrm{Cd}$ & $0.09575 \pm 0.09820$ & 0.367 & $0.02750 \pm 0.0982$ & 0.789 & $0.12325 \pm 0.09820$ & 0.256 \\
\hline
\end{tabular}

\section{DISCUSSION}

Lead contents in the soils varied significantly from site to site. $\mathrm{Pb}$ content in soils ranged from $0.5-4.00 \mathrm{mg} / \mathrm{kg}$ along the entire roadside soil sampled. Its concentrations were higher than WHO/FAO (2001) limit. This result is consistent with the report of Oyedele \& Funtua (2001) on Kaduna- Zaria highway Nigeria. The range value for $\mathrm{Pb}$ in this study is lower compared to FCT soils (Kabiru et al., 2015), Bauchi soils (Kakulu, 1989), Urban soils of Amman, Jordan (Jiries, 2003), and Urban soils of Lagos, Nigeria (Atayese et al., 2009), Aba soils (Ijeoma \& Princewilll, 2011), and soils of Honolulu, USA (Sutherland et al., 2000). It is, however, higher (0.013 \pm $0.006-0.225 \pm 0.020 \mu \mathrm{g} / \mathrm{g}$ ) in soils of Malaysia (Yap et al., 2010). Furthermore, high $\mathrm{Pb}$ levels have also been reported in roadside soil along sampling points with heavy vehicular emissions (especially patronizing the mechanic and block industry) by various researchers (Othman et al., 1997; Al-Chalabi \& Hawker, 2000; Ubwa et al., 2013; Olayiwola, 2013). Lead pollution in urban soil has been attributed to combustion of gasoline that contains tetraethyl lead used as anti-knock agent. Ragwan et al .(2015) opined that the level of $\mathrm{Pb}$ could be increased with decreased $\mathrm{pH}$ of soil samples due to the presence of other ions causing exchanged hydrogen ions into the solution, thus decreasing the $\mathrm{pH}$ of solution. In this study, $\mathrm{Pb}$ content decreased with increase in distance. It has been reported that Lead content in soil increases steeply close to a highway with high volume of traffic (Alloway, 1996). However, concentration of lead in the soil could be from automobile exhaust fumes as well as dry cell batteries, sewage effluents, runoff of wastes and atmospheric depositions which could cause its bioaccumulation in plant via uptake from the soil and eventual entry into the food chain (Opaluwa et al., 2012). It was revealed by Atuanya et al. (2003) that higher lead concentration in soils has toxic effect on microorganisms inhabiting the soil which consequently alters the flora and fauna of a location. Lead is known for lead poisoning in humans as well as chronic neurological disorders especially in foetus and children hypertension, and other respiratory problems in adults.

The soil concentrations of $\mathrm{Cu}$ were between the ranges 3.91-8.59 $\mathrm{mg} / \mathrm{kg}$, lower than the permissible limit recommended by Dutch standard of $36 \mathrm{mg} / \mathrm{kg}$. The value of $\mathrm{Cu}$ recorded in the soil samples was highest along Owerri-Onitsha road, Owerri-PortHarcourt road and Owerri-Aba road at $10 \mathrm{~m}$ distance, which agrees with some other reported studies from N-5 Pakistan (Khan et al., 2011), Lithuania's highways (Jankaitè et al., 2008). However, the value is much lower than the ones obtained from North Central Nigeria, $80.13 \mathrm{mg} / \mathrm{kg}$ (Ogundele et al., 2015), A-71 Motorway in France Highway, Istanbul, $122.37 \mathrm{mg} / \mathrm{kg}$ (Sezgin et al., 2003). Copper is a microelement which is essential in plant growth and occurs generally in soil, sediments and air. $\mathrm{Cu}$ content has been reported to differ according to the soil type and pollution source. Fatoki \& 
Ayodele (1991) opined that $\mathrm{Zn}$ and $\mathrm{Cu}$ concentrations in soil are functions of traffic density. The high concentration in some locations may be as a result of burnt vehicles along the major roads as copper is commonly found in electrical wirings, engine wear, brake linings (Manno et al., 2006). This could find its way into the roadside soils.

The concentration range for $\mathrm{Cd}$ in the soil sample was 0.32 $-0.55 \mathrm{mg} / \mathrm{kg}$. The concentration of $\mathrm{Cd}$ decreased with the increase of distance and reaches a relatively low value $(0.97$ $\mathrm{mg} / \mathrm{kg}$ ) at $20 \mathrm{~m}$ from the road edge. The observed concentration values of $\mathrm{Cd}$ were much higher than the background value $(0.31 \mathrm{mg} / \mathrm{kg})$. The level of $\mathrm{Cd}$ in this study is lower than values obtained in soils of Malaysia (Yap et al., 2010). Some studies gave a result of $5.2 \mu \mathrm{g} / \mathrm{g}$ in roadside soils in Lancaster (Harrison et al., 1981), and $4.2 \mu \mathrm{g} / \mathrm{g}$ on a highway roadside soil in London (Culbard et al., 1988). The results obtained in this study were within the range of reported results obtained in Hong Kong and Lagos, Nigeria (Ndiokwere, 1984). Sources of Cd in the urban areas could be more from metal plating and lubricating oils. It could also be due to rough surfaces of the roads which increase the wearing of tyres, and run-offs from the roadsides (Ho \& Tai, 1988). Also, human activities can contribute to increased Cd levels as a result of urban-industrial activities and/or agricultural practices. McBride (1994) opined that concentrations above $0.5 \mathrm{mg} / \mathrm{kg}$ could reflect the influence of human activity. In the study, some locations exceeded this value, indicating a slight increase in this heavy metal in relation to the normal level.

$\mathrm{Zn}$ ranged from $3.97 \mathrm{mg} / \mathrm{kg}$ (control site) to $8.59 \mathrm{mg} / \mathrm{kg}$ (Owerri-Onitsha road) at $20 \mathrm{~m}$ to $10 \mathrm{~m}$ distance. This value is low compared with many other studies (Jaradat \& Momani, 1999; Bai et al., 2009). The observed level is lower than 30.8 $\mathrm{mg} / \mathrm{kg}-219.23 \mathrm{mg} / \mathrm{kg}$, reported in roadside soil of Nigeria (Ogundele et al., 2015), 300-530 $\mu \mathrm{g} / \mathrm{g}$ reported in Lancaster (Harrison et al, 1981), and $25.68 \pm 4.67 \mathrm{mg} / \mathrm{kg}$ reported for $10 \mathrm{~m}$ from roadside soil in Osogbo, Nigeria (Fakayode \& Olu-Owolabi, 2003). In Alicante, Spain, an average $\mathrm{Zn}$ content of $57.8 \mathrm{mg} / \mathrm{kg}$ was reported by Mico et al. (2006); $80.7 \mathrm{mg} / \mathrm{kg}$ was reported in a study in Assiut, Egypt. About $0.51 \mathrm{mg} / \mathrm{kg}$ was reported in a study carried out in China (Mico et al. 2006) which is lower than the observed level in this study. In this study, the $\mathrm{Pb} / \mathrm{Zn}$ ratio in soil was less than unity as it has been reported that soil-lead pollution may be caused by automobiles. However, other reports found a ratio of less than unity, which was related to the local conditions (Hewitt \& Candy, 1990). Since no major industry exists in the study areas such as smelting operations, we may assume that the primary sources of $\mathrm{Zn}$ are probably the attrition of motor vehicle tire rubber exacerbated by poor road surfaces, and the lubricating oils in which $\mathrm{Zn}$ is found as part of many additives example zinc dithiophosphates (Abechi et al., 2010). Thus, the probable sources of $\mathrm{Zn}$ on this highway could be due to deposits from automobiles and other anthropogenic activities.

The concentration of Nickel in the present study like the other metals decreased with increase in distance. Decreasing metal concentration with increasing distance from the road might be due to heavy metal emitted from vehicle exhaust in particulate forms which are forced to settle under gravity closer to road edges (Haygarth \& Jones, 1992) as cited by
Amusan et al. (2003). However, other studies reported higher mean values, $99.80 \mathrm{mg} / \mathrm{kg}$ at Nigde -Adana Highway (Yalcin et al., 2007), $26.70 \mathrm{mg} / \mathrm{kg}$ at Beijing (Chen et al., 2010), $128.82 \mathrm{mg} / \mathrm{kg}$ at Edrine Turkey (Aktas et al., 2010). Similar results were obtained in soils of Valencia, and in the fertile Granada Valley (Campos, 1997). The normal soil Ni content varies from 1 to $100 \mathrm{mg} / \mathrm{kg}$ (Kabata-Pendias \& Pendias, 2001). In this study all sampled soils were below this range. None of agricultural soils exceeded the reference value of Pérez et al. (2002) for agricultural soils in Murcia and all of them were below the maximum permissible concentration (Kabata-Pendias \& Pendias, 2001). Comparing with the control sample, it has been observed that roadside samples are more contaminated with Nickel. Vehicular traffic is the most probable source of Nickel on roadside soil. The concentration of $\mathrm{Pb}, \mathrm{Zn}$ and $\mathrm{Cd}$ showed a mean value with no significant difference for the three sampled location and control, while the values for $\mathrm{Cu}$ and $\mathrm{Ni}$ showed a high level of significance at $\mathrm{p}<0.05$. Though there was no significant difference in the mean concentration of the heavy metals $(\mathrm{Pb}$, $\mathrm{Zn}$ and $\mathrm{Cd}$ ), their values show an increasing trend as one moves from the $20 \mathrm{~m}$ region to the $10 \mathrm{~m}$ region.

\section{REFERENCES}

[1] Abechi, E.S., Okunola, O.J., Zubairu, S.M., Usman, A.A. and Apene, E. (2010). Evaluation of heavy metals in roadside soils of major streets in Jos metropolis, Nigeria. Journal of Environmental Chemistry and Ecotoxicology. 2(6):98-102

[2] Achadu, O.J., Goler, E.E., Ayejuyo, O.O., Olaoye, O.O. and Ochimana, O.I. (2015). Assessment of heavy metals (Pb, Cd, $\mathrm{Zn}$ and $\mathrm{Cu}$ ) concentrations in soils along a major highway in Wukari, North-Eastern Nigeria. Journal of Biodiversity and Environmental Sciences. 6(2): 1-7,

[3] Adelasoye, K.A and Ojo, O.A (2014). Accumulation of heavy metal pollutants in soil and cassava leaf and their effects on soil microbial population on roadsides in Ogbomoso, Nigeria.International Journal of Applied Agriculture and Apiculture Research. 10:1-2

[4] Aktas Y. K. and Kocabas A. (2010), Heavy metal content of roadside soil in Edirne, Turkey. Analytical Letters, 43:1869-1878

[5] Al-Chalabi, A. and Hawker, D. (2000). Distribution of vehicular lead in roadside soils of major roads of Brisbane, Austria. Water, Air and Soil Pollution. 118: 299-310.

[6] Alloway, B. S. (1996). Heavy Metals in Soil. Halsteed press, John Wiley and Sons Inc. London: pp. 339.

[7] Amusan, A., Bada, S. and Salami, A. (2003). Effect of traffic density on heavy metal content of soil and vegetation along roadsides in Osun state, Nigeria. West African Journal of Applied Ecology 4:107-144.

[8] Atayese, M.O., Eigbadon, A.I., Oluwa, K.A. and Adesodun, J.K (2009). Heavy metal contamination of Amaranthus grown along major highways in Lagos. African Crop Science Journal 16:225-235

[9] Atuanya, E. I, Obuekwe, C.O and Ehigie, S.O (2003) Microbial studies and lead tolerance levels of microbes in lead accumulator dumps. Journal of Environmental Science and Health2: 8 - 13.

[10] Bai, J., Cui, B., Wang, Q., Gao, H. and Ding, Q. (2009). Assessment of heavy metal contamination of roadside soils in Southwest China.Stochastic Environmental Research and Risk Assessment, 23 (3): 341-347.

[11] Campos, E. (1997). Estudio de la contaminación y fraccionamiento químico de metales pesados en suelos de la Vega de Granada. Doctoral Thesis. University of Granada, Granada, Spain.

[12] Censi, P., Spoto, S.E., Saiano, F., Sprovieri, M., and Mazzola, S (2006). Heavy metals in coastal water system. A case study from the North Western Gulf of Thailand. Chemosphere, 64: 1167-1176.

[13] Chen, S., Yao, H., Han, J., Liu, C., Song, J. and Shi, L. (2010). Validation of the ITS2 Region as a Novel DNA Barcode for Identifying Medicinal Plant Species. PLoS ONE 5(1): 8613.

[14] Christopher I. A. and Therese N. N. (2010). Heavy Metal Contamination of Surface Soil in Relationship to Land Use Patterns: A Case Study of Benue State, Nigeria. Journal of Materials Sciences and Applications, 1: 127-134. 
[15] Culbard, E.B, Thornton, I., Watt, J., Weatley, M., Moorcraft, S. and Thompson, M. (1988). Metal contamination in British suburban dusts and soils. Journal of Environmental Quality17, 226-234.

[16] DPR-EGASPIN, (2012). Environmental guidelines and standards for the petroleum industry Nigeria (EGASPIN) Department of petroleum industry in Nigeria.

[17] Edelman, T. and Bruin, M.D. (1986). Background values of 32 elements in Dutch topsoils, determine with non-destructive neutron activation analysis. P. 89-99. In: J.W. Assink (ed). Contaminated Soil. Martinus Nijhoff Publ. Dardrecht, the Netherlands.

[18] Fakayode, S.O. and Olu-Owolabi, B.I. (2003). Heavy metal contamination of roadside topsoil in Osogbo, Nigeria: its relationship to traffic density and proximity to highways. Environmental Geology.44:150-157.

[19] Fatoki, O.S and Ayodele, E.T. (1991). Zinc and Copper in tree barks as indicators of environmental pollution.International Environment. 17:155-160

[20] Harrison, R.M., Laxen, D.P. and Wilson, S.J. (1981). Chemical Association of Lead, Cadmium, Copper, and Zinc in Street Dusts and roadside soils. Environmental Science and Technology. 15: 1378-1383.

[21] Haygarth, P.M and Jones, K.C. (1992). Atmospheric deposition of metal to agricultural surface. Biogeochemistry of Trace Metals. Ed D.C Adriano pp 249-276 CRC Press, Boca Rola

[22] Hewitt C.N. and Candy, G. B. (1990). Soil and street dust heavy metal concentration in and around Ecuador. Environmental Pollution. 63(2):129-136

[23] Ho, I.B. and Tai, K.M.(1988). Elevated levels of lead and other. Metals in roadside soil and grass and their use to monitor aerial metal depositions in Hong Kong. Environ. Pollut.49: 37-51.

[24] Ihenyen, A.E. (1998) Assessment of heavy metal pollution in roadside sediments in Benin City, Nigeria.Geologia. 3:187-197

[25] Ijeoma, L.P. and Princewill, C.O. (2011). Heavy Metal Content in Soil and Medicinal Plants in High Traffic Urban Area. Pakistan Journal of Nutrition, 10: 618-624.

[26] Jankaite, A ., Baltrènas, P. and Kazlauskienè, A . (2008). Heavy metal concentrations in roadside soils of Lithuania's highways. Geologija. 4(64):237-245.

[27] Jiries, A. (2003). Vehicular Contamination of Dust in Amman, Jordan. The Environmentalist 23: 205.

[28] Kabata-Pendias, A. and Pendias, H. (2001). Trace Elements in Soils and Plants. 3rd edition. CRC Press, Boca Raton, Florida, pp 413.

[29] Kabiru, S., Yakubu, R., Lukman, A., Akintola, T. and Mathias, A. (2015). Heavy Metal Content in Soil in Garki Area Council of Federal Capital Territory, Abuja, Nigeria. Biochemistry \& Analytical Biochemistry. 4: 197

[30] Kakulu, S.E. (1989) A baseline atmosphere heavy metal deposition in northern Nigeria. Indian Journal of Ecology16: 1-6.

[31] Khan, M. N., Wasim, A. A., Sarwar, A. and Rasheed, M. F. (2011). Assessment of heavy metal toxicants in the roadside soil along the N-5, National Highway, Pakistan.Environmental Monitoring and Assessment, 182:587-595.

[32] Kudirat, L.M. and Funmilayo, D.V. (2011). Heavy metal levels in vegetables from selected markets in Lagos, Nigeria. African Journal of Food Science and Technology, 2(1):18-26

[33] Kuhad, M.S., Malik, R.S. and Singh, A. (1989). Background levels of heavy metals in agricultural soils of Indo-Gangetic Plains of Haryana.Journal of the Indian Society of Soil Science. 37: 700 - 705.

[34] Li, X.D., Poon, C.S. and Liu,P.U. (2001). Heavy metal contamination of urban soils and street dusts in Hong Kong. Applied Geochemistry16: 1361-1368.

[35] Liu, W.H., Zhao, J.Z. and Ouyang, Z.Y. (2005). Impacts of sewage irrigation on heavy metal distribution and contamination in Beijing, China. Environment International, 31: 805-812

[36] Luilo, G. B. and Othman, O. C. (2006). Lead Pollution in urban roadside environments of Dares Salaam city. Tanzania Journal of Science. 32 (2): 61-67.

[37] Manno, E., Varrica, D. and Dongarra, G. (2006). Metal distribution in road dust samples collected in an urban area close to a petrochemical plant at Gela, Sicily. Atmosphere and Environment 40, 5929-5941.

[38] McBride, M.B. (1994). Environmental Chemistry of Soils. Oxford University Press, New York.

[39] Micó, C., Peris, M., Sánchez, J. and Recatalá, L. (2006). Heavy metal content of agricultural soils in a Mediterranean semiarid area: the Segura River Valley (Alicante, Spain). Spanish Journal of Agricultural Research. 4(4): p. 363-372.

[40] Mmolawa, K.B., Likuku, A.S. and Gaboutloeloe, G.K. (2011). Assessment of heavy metal pollution in soils along major roadside areas in Botswana. African Journal of Environmental Science and Technology, 5(3):186-196.
[41] Ndiokwere, C.L. (1984) A study of heavy metal pollution from motor vehicle emissions and its effect on roadside soil, vegetation and crops in Nigeria. Environmental Pollution Series B, Chemical and Physical, 7(1):35-42.

[42] Ogundele, D.T, Adio, A..A and Oludele, O.E (2015). Heavy Metal Concentrations in Plants and Soil along Heavy Traffic Roads in North Central Nigeria. Journal of Environmental and Analytical Toxicology5: 334.

[43] Okereke, J. N., Nwachukwu, A. A., Ukaoma, A. A. and Udeja, A. I (2014). Evaluation of Heavy metals in Soils and Fertilizers Commonly applied on Agricultural Lands in Idemili Anambra State, Nigeria. International Journal for Environmental Health \& Human Development, 15(2): $12-17$.

[44] Olatunji, S. O., Opeolu, B.O., Fatoki, O.S. and Ximba, B.J. (2013). Heavy metals concentration levels in selected arable agricultural soils in South Western Nigeria. International Journal of Physical Science. $8(11): 421-427$

[45] Olayiwola, O.A. (2013). Accumulation and Contamination of Heavy Metals in Soil and Vegetation from Industrial Area of Ikirun, Osun State, Nigeria. European American Journal. 6:25-34

[46] Opaluwa, O. D, Aremu, M. O, Ogbo, L. O, Abiola, K. A., Odiba, I. E, Abubakar, M. M. and Nweze, N.O (2012). Heavy metal concentrations in soils, plant leaves and crops grown around dump sites in Lafia Metropolis, Nasarawa State, Nigeria. Advances in Applied Science Research, 3 (2):780-784

[47] Osuocha, U.K, Chukwu, E.C, Ezekwe, A.S, Imo, C, Charles, S.U, Ibe, C. and Ikpo, J.C (2014). Heavy metal bioaccumulation of selected tuber crops from Ishiagu, Ebonyi State, South East, Nigeria. Journal of Biodiversity and Environmental Sciences. 5(2):136-140

[48] Othman, I. Al Oudat, M. and Al Masri, M.S. (1997). Lead levels in roadside soils and vegetation of Damascus city.Science of the Total Environment. 207:43-48.

[49] Oyedele, A.O. and Funtua, I.I. (2002). Lead, Copper, Zinc level in soils along Kaduna-Zaria highway, Nigeria. Global journal of Environmental Science. 1(1):1-13

[50] Perez, C., Martinez, M., Vidal, J. and Navarro, C. (2002). Proposed reference values for heavy metals in calcaric fluvisols of the Huerta de Murcia (SE Spain). In: Sustainable Use and Management Of Soils in Arid and Semiarid Regions (Fáz A., Ortiz R., Mermut A.R., eds). Quaderna Editorial, Cartagena, Murcia, Spain, pp. 495-496.

[51] Poszyler-Adamska, A. and Czemiak, A. (2007). Biological and chemical indication of roadside ecotonic zones. Journal of Environmental Engineering and Landscape Management, 15(2):113a-118a

[52] Ragwan, M., Mohamed, E., Khadija, A., Fatma, A., and Zarouk, A. (2015). Assessment of Heavy Metal Contamination in Soils of Sirte City, Libya. 2nd Int'l Conference on Advances in Environment, Agriculture \& Medical Sciences. 2:62-68

[53] Sezgin, N., Ozcan, H. K., Demir, G., Nemlioglu, S. and Bayat, C, (2003), Determination of heavy metal concentrations in street dusts in Istanbul E-5 Highway. Environment International, 29, pp 979-985.

[54] Sutherland, R.A, Tolosa, C.A, Tack, F.M, and Verloo, M.G (2000) Characterization of selected element concentration and enrichment ratios in background and anthropogenically impacted roadside areas.Archives ofEnvironmental Contaminationand Toxicology. 38: 428-438.

[55] Taofeek, A.Y and Tolulope, O .O. (2012). Evaluation of some Heavy Metals in Soils along a Major Road in Ogbomoso, South West Nigeria. Journal of Environment and Earth Science2(8): 2224-3216.

[56] Ubwa, S.T, Abah, J, Ada, C.A, Alechenu, E. (2013). Levels of some heavy metals contamination of street dust in the industrial and high traffic density areas of Jos Metropolis. Journal of Biodiversity and Environmental Sciences3(7):13-21.

[57] WHO/FAO (2001). Soil testing and plant analysis, Bullentin. No 38/1, Food and Agriculture Organization, Rome, Italy. 2009;7-12.

[58] Yalcin, M.G., Battaloglu, R., Ilhan, S., Tumuklu, A. and Topuz, D. (2007), Heavy metal contamination along the Nigde- Adana Highway, Turkey. Asian Journal of Chemistry, 19: pp 1506-1518.

[59] Yap, C.K., Mohd, Fitr., M.R, Mazyhar, I.Y. and Tan, S.G. (2010). Effects of metal contaminated soils on the accumulation of heavy metal in different parts of Centella asiatica: Sains Malaysia 39: 347-352.

[60] Zauro, S.A., Dabai, M. U., Tsafe, A. I., Umar, K.J. and Lawal, A.M (2013). Extent of some heavy metal contamination in soils of farmlands around Sokoto metropolis, European Scientific Journal. 9(3): 1857 7881 